\title{
Theoretische modellen over werkstress
}

Jan de Jonge, Pascale Le Blanc en Wilmar Schaufeli

$2.1 \quad$ Inleiding - 24

2.2 Person-Environment Fit Model - 25

2.2.1 Inhoud -25

2.2.2 Empirische evidentie -26

2.2.3 Kanttekeningen -27

2.3 Demand-Control(-Support) Model - 27

2.3.1 Inhoud - 27

2.3.2 Empirische evidentie - 29

2.3.3 Kanttekeningen -30

$2.4 \quad$ Vitaminemodel - 32

2.4.1 Inhoud - 32

2.4.2 Empirische evidentie - 34

2.4.3 Kanttekeningen -35

2.5 Effort-Reward Imbalance Model - 35

2.5.1 Inhoud - 35

2.5.2 Empirische evidentie - 37

2.5.3 Kanttekeningen -37

2.6 Job Demands-Resources Model - 38

2.6.1 Inhoud - 38

2.6.2 Empirische evidentie - 39

2.6.3 Kanttekeningen -40

2.7 Demand-Induced Strain Compensation Model - 41

2.7.1 Inhoud - 41

2.7.2 Empirische evidentie - 43

2.7.3 Kanttekeningen -43

$2.8 \quad$ Slotbeschouwing -44

Aanbevolen literatuur - 45 
I) 'He who loves practice without theory is like the sailor who boards ship without a rudder and compass and never knows where he may be cast.'

Leonardo da Vinci (1452-1519) 《

\subsection{Inleiding}

Werknemers in geïndustrialiseerde landen hebben de afgelopen jaren in toenemende mate te maken gehad met veranderingen in en rondom de arbeid. Zo is er sprake van een intensivering van de arbeid, zich uitend in een hogere werkbelasting. Ook is de werkbelasting verschoven van fysieke belasting naar mentale en emotionele belasting, onder andere ten gevolge van de toename van het aantal werknemers dat in de dienstensector werkzaam is. Verder is er sprake van een bijna continu proces van organisatieverandering en worden er voortdurend nieuwe productie- en managementconcepten ingevoerd. Ten slotte wordt het psychologisch contract, dat wil zeggen de verwachting die werknemers koesteren over een billijke verhouding tussen hun inspanningen ten behoeve van de organisatie en de materiële en immateriële beloning die daartegenover staat, in toenemende mate aangetast. Tezamen zorgen deze veranderingen in en rondom de arbeid ervoor dat de risico's verbonden aan het verrichten van arbeid steeds meer verschuiven van het materiële en fysieke vlak naar het psychosociale vlak, zoals geconcludeerd in $>$ H. 1. Psychosociaal heeft, zoals het woord al zegt, te maken met cognitieve, emotionele en sociale aspecten die invloed uitoefenen op de werknemer. Voorbeelden van psychosociale risicofactoren zijn: werkdruk, confrontatie met lastige en agressieve cliënten, gebrek aan controle over de uitvoering van het werk, conflicten met collega's en baanonzekerheid. Daarnaast groeit het inzicht dat deze psychosociale kenmerken van het werk eveneens bepalend kunnen zijn voor de kwalitatieve en kwantitatieve werkprestatie.

Op het terrein van de A\&G-psychologie bestaat een grote belangstelling voor psychosociale werkkenmerken als determinanten van de gezondheid en het welbevinden van werknemers. Uit onderzoeksliteratuur blijkt namelijk dat werkkenmerken zoals werkdruk en gebrek aan regelmogelijkheden (autonomie) samenhangen met bijvoorbeeld burnout en arbeidsontevredenheid (Alcaron, 2011). Deze manifestaties van ongezondheid en onwelbevinden kunnen op den duur leiden tot arbeidsverzuim en arbeidsongeschiktheid (zie $\triangleright$ H. 12 en $\triangleright$ H. 20). Aan de andere kant horen we ook positieve geluiden over arbeid. De combinatie van werkdruk en voldoende regelmogelijkheden geeft juist energie en veerkracht, maakt ontwikkeling en groei mogelijk, en roept positieve gevoelens op zoals motivatie, tevredenheid, trots en toewijding (zie $\checkmark$ H. 17). Inzicht in de psychologische processen die hieraan ten grondslag liggen, is daarom van groot belang

\section{Box 2.1 Werkstress}

Tegenwoordig lijken we allemaal wel eens last te hebben van stress, vooral van stress op het werk. De term stress heeft in de volksmond vooral de betekenis van een gespannen toestand. Van buitenaf wordt er druk op iemand uitgeoefend, hetgeen kan resulteren in een gevoel van spanning ('strain' of stressreacties). Deze externe druk wordt ook wel een stressor genoemd. De persoon zal normaliter in staat zijn om deze druk op te vangen, zich aan te passen aan de situatie en weer te herstellen. De mate waarin dit mogelijk is, wordt echter mede bepaald door de aanwezigheid van hulpbronnen ('resources') in de (werk)omgeving (bijv. ondersteuning door de chef of een familielid) en door persoonlijke hulpbronnen (zoals de wijze van omgaan met problemen). Stress ontstaat wanneer de externe druk zo hoog 
is dat de grens van het persoonlijk aanpassingsvermogen wordt overschreden als gevolg van (de combinatie van) te veel stressoren en te weinig hulpbronnen, en de persoon niet meer in staat is om de hieruit voortkomende spanning te verminderen. Stress in of door de werksituatie wordt werkstress genoemd. De meest gangbare opvatting van werkstress in de onderzoeksliteratuur is een toestand waarin een werknemer niet in staat is, of zich niet in staat acht, om aan de door de werkomgeving gestelde eisen te voldoen (Gaillard, 2003).

De laatste decennia zijn diverse theoretische modellen over werkstress (zie $\boldsymbol{b}$ box 2.1) ontwikkeld. De ontwikkeling van deze modellen had tot gevolg dat men conceptuele en praktisch relevante vragen in theoretische raamwerken kon gieten en ze vervolgens systematisch kon onderzoeken. Het Person-Environment Fit Model (French, Rogers \& Cobb, 1981) en het DemandControl(-Support) Model (Karasek \& Theorell, 1990) zijn hiervan sprekende voorbeelden. De toonaangevende modellen op het terrein van het voorspellen en verklaren van werkstress, gezondheid en welbevinden zullen achtereenvolgens besproken worden in de paragrafen 2.2 tot en met 2.7. Hierbij zal een onderscheid gemaakt worden naar de inhoud van en de empirische evidentie voor de geldigheid van elk model, en zullen er kanttekeningen bij ieder model geplaatst worden.

\subsection{Person-Environment Fit Model}

\subsubsection{Inhoud}

Aan het Amerikaanse Institute for Social Research (ISR) van de Universiteit van Michigan te Ann Arbor werd in het begin van de jaren zestig van de vorige eeuw een onderzoeksprogramma ten aanzien van de sociale (werk)omgeving en mentale gezondheid opgezet (Kahn e.a., 1964). Vanuit deze traditie ontstond het Person-Environment Fit Model (P-E Fit Model), dat ervan uitgaat dat stress niet afzonderlijk door de persoon of de omgeving veroorzaakt wordt, maar door de zogeheten passing ('fit'), of beter gezegd geen passing ('misfit'), tussen beide. Volgens het P-E Fit Model (zie - Figuur 2.1) kan werkstress gedefinieerd worden als een 'misfit' tussen de persoonlijke behoeften en de hulpbronnen in de (werk)omgeving, dan wel een 'misfit' tussen de persoonlijke mogelijkheden en de eisen vanuit de (werk)omgeving. Er kan bijvoorbeeld een 'misfit' bestaan tussen de wens om zich verder te ontwikkelen op het werk (persoonlijke behoefte) en het scholingsbudget van het bedrijf (hulpbron in de omgeving). Of er kan een 'misfit' bestaan tussen hoe snel een werknemer kan werken (persoonlijke mogelijkheid) en de vereiste productienorm (omgevingseis).

Daarnaast wordt er in het model onderscheid gemaakt tussen objectieve en subjectieve 'misfit' (ofwel Mo en Ms; zie - Figuur 2.1). De objectieve 'misfit' betreft een discrepantie tussen de feitelijke toestand waarin de werknemer zich bevindt en de objectieve kenmerken van de werkomgeving. De subjectieve 'misfit' heeft betrekking op een discrepantie tussen de kijk van een werknemer op zichzelf en zijn kijk op de (werk)omgeving.

Een andere belangrijke vooronderstelling van het P-E Fit Model is dat zowel een positieve 'misfit' (bijv. een werknemer heeft meer persoonlijke mogelijkheden dan de omgeving vereist) als een negatieve 'misfit' (de persoon heeft minder mogelijkheden dan de omgeving eist) leidt tot stressreacties. Kortom, er wordt een relatie tussen P-E Fit en stressreacties verondersteld, die U-vormig of omgekeerd U-vormig kan zijn. 


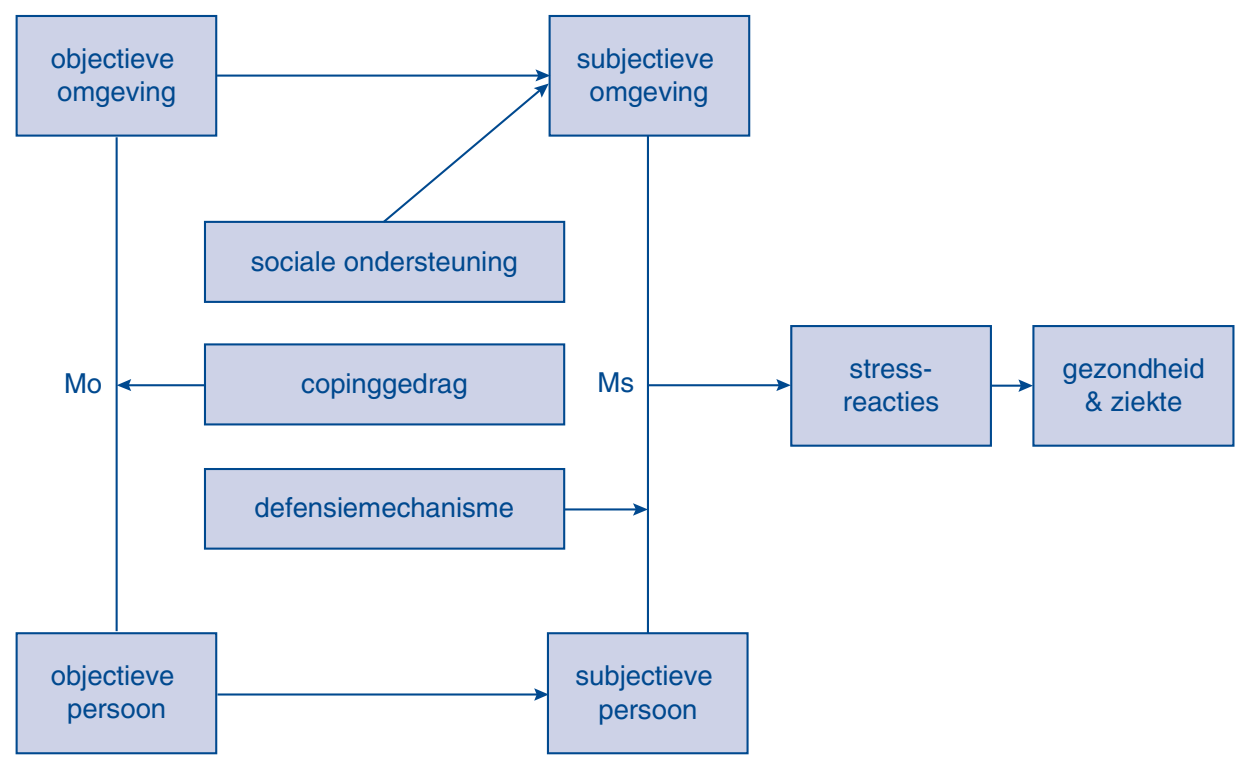

Figuur 2.1 Person-Environment Fit Model. Bron: French (1981).

Tot slot kunnen in het model drie mechanismen worden onderscheiden die enerzijds betrekking hebben op het hanteren van stressvolle situaties (ook wel copinggedrag genoemd) en anderzijds op het waarnemen van sociale ondersteuning. Deze mechanismen worden geacht de 'misfit' tussen persoon en (werk)omgeving te verminderen.

- Het eerste, actieve copingmechanisme (in - Figuur 2.1 gelabeld als copinggedrag) heeft tot doel de 'misfit' tussen de objectieve persoon en de omgeving te verminderen (bijv. door actief en oplossingsgericht met problemen om te gaan).

- Het tweede, passieve copingmechanisme (in - Figuur 2.1 defensiemechanisme genoemd) heeft als doel de (waargenomen) 'misfit' tussen de subjectieve persoon en de omgeving te reduceren (bijv. door verdringing of projectie).

- Subjectieve sociale ondersteuning is de waargenomen hoeveelheid steun van de leidinggevende, collega's, familie of vrienden. Deze steun wordt verondersteld de subjectieve omgeving rechtstreeks te beïnvloeden.

\subsubsection{Empirische evidentie}

Sinds de ontwikkeling van het P-E Fit Model zijn er talloze empirische studies naar het model uitgevoerd. Edwards (1991) heeft veel van deze studies samengevat en beoordeeld, en kwam tot de volgende conclusies:

1. de meeste empirische studies hebben zich gericht op de 'misfit' tussen behoeften en hulpbronnen (i.p.v. mogelijkheden en vereisten);

2. het merendeel van de onder 1 genoemde studies vond significante relaties tussen 'misfit' en stressreacties (bijv. arbeidsdissatisfactie, vermoeidheid, lichamelijke klachten en arbeidsverzuim);

3. in enkele studies is gekeken naar de 'misfit' tussen persoonlijke mogelijkheden en omgevingsvereisten, en werd het bestaan van kromlijnige relaties met stressreacties bevestigd. 


\subsubsection{Kanttekeningen}

Een eerste kanttekening bij het P-E Fit Model is dat het model vrij breed van opzet is. Zo is bijvoorbeeld niet gespecificeerd welke stressoren onderzocht kunnen worden. Het model is dan ook meer een samenvoeging van een aantal conceptuele categorieën dan een weerspiegeling van een bepaalde theorie. Hoewel het P-E Fit Model verschillende mechanismen en vooronderstellingen kent, is in de meeste studies enkel gekeken naar de 'misfit' tussen de subjectieve persoon en omgeving. Een 'echte' objectieve misfit tussen persoon en omgeving blijkt ook moeilijk te bepalen (zie Tinsley, 200o). Daarnaast kent de operationalisering van de P-E Fit-maat zowel theoretische als methodologische problemen. Er is bijvoorbeeld geen adequate theorie (en hypothese) met betrekking tot de vraag in welke gevallen de P-E Fit bepaald moet worden aan de hand van 'behoeften en voorzieningen' en in welke gevallen aan de hand van 'mogelijkheden en vereisten' (zie ook - Figuur 2.1). Een voorbeeld van een methodologisch probleem is hoe precies de P-E Fit-variabele wiskundig geformuleerd dient te worden met het gevaar van allerlei soorten vertekening of misinterpretatie.

\subsection{Demand-Control(-Support) Model}

\subsubsection{Inhoud}

Geïnspireerd door de onderzoekstradities van de jaren zestig en zeventig van de vorige eeuw, bemerkte de Amerikaanse architect en socioloog Robert Karasek (1979) dat een beperkt aantal arbeidsgebonden psychosociale risico's gecombineerd kan worden in een eenvoudig theoretisch kader. Karasek en zijn collega's ontwikkelden vanuit dit besef het Demand-Control Model (DC Model; zie Karasek \& Theorell, 1990; Theorell \& Karasek, 1996). Dit model was enkele decennia een van de meest gebruikte werkstressmodellen binnen de A\&G-psychologie.

Het DC Model is een omgevingsgericht model, dat schematisch en tweedimensionaal weergegeven wordt in $\boldsymbol{0}$ Figuur 2.2. In het model worden twee psychosociale werkkenmerken beschouwd als belangrijke determinanten van de gezondheid en het welbevinden van werknemers: psychologische taakeisen ('psychological job demands') en regelmogelijkheden ('job decision latitude' of 'job control'). Psychologische taakeisen worden door Karasek gedefinieerd als psychologische stressoren, aanwezig in de werkomgeving (bijv. grote tijdsdruk, hoog werktempo, moeilijk en geestelijk inspannend werk). Het gaat hierbij dus niet alleen om de hoeveelheid werk maar ook om de complexiteit ervan. De term regelmogelijkheden kan omschreven worden als de controle van een werknemer over zijn taken en zijn gedrag: hoe hij het werk uitvoert, in welk tempo en in welke volgorde (Karasek, 1979). Deze controle kan tevens beschouwd worden als het zelfregulerende vermogen van een werknemer om de aanwezige stressoren te beïnvloeden, zodat zij binnen aanvaardbare grenzen blijven (zie ook $>$ H. 3).

Het DC Model gaat uit van twee centrale veronderstellingen, weerspiegeld door de diagonalen A en B in - Figuur 2.2. De eerste veronderstelling (diagonaal A) is dat stressreacties zoals psychische vermoeidheid en hart- en vaataandoeningen, voornamelijk veroorzaakt worden door de combinatie van hoge taakeisen en weinig regelmogelijkheden (kwadrant 1: 'veel spanning'). Deze combinatie wordt door Karasek omschreven als een interactie-effect (zie ook - H. 10): de effecten van taakeisen op stressreacties variëren ten gevolge van de hoeveelheid regelmogelijkheden in het werk. Anders gezegd: regelmogelijkheden bufferen de nadelige gevolgen van taakeisen op allerlei stressreacties. Een tegenovergestelde werksituatie wordt aangetroffen in kwadrant 3 van - Figuur 2.2: werk met lage taakeisen en veel regelmogelijkheden. 


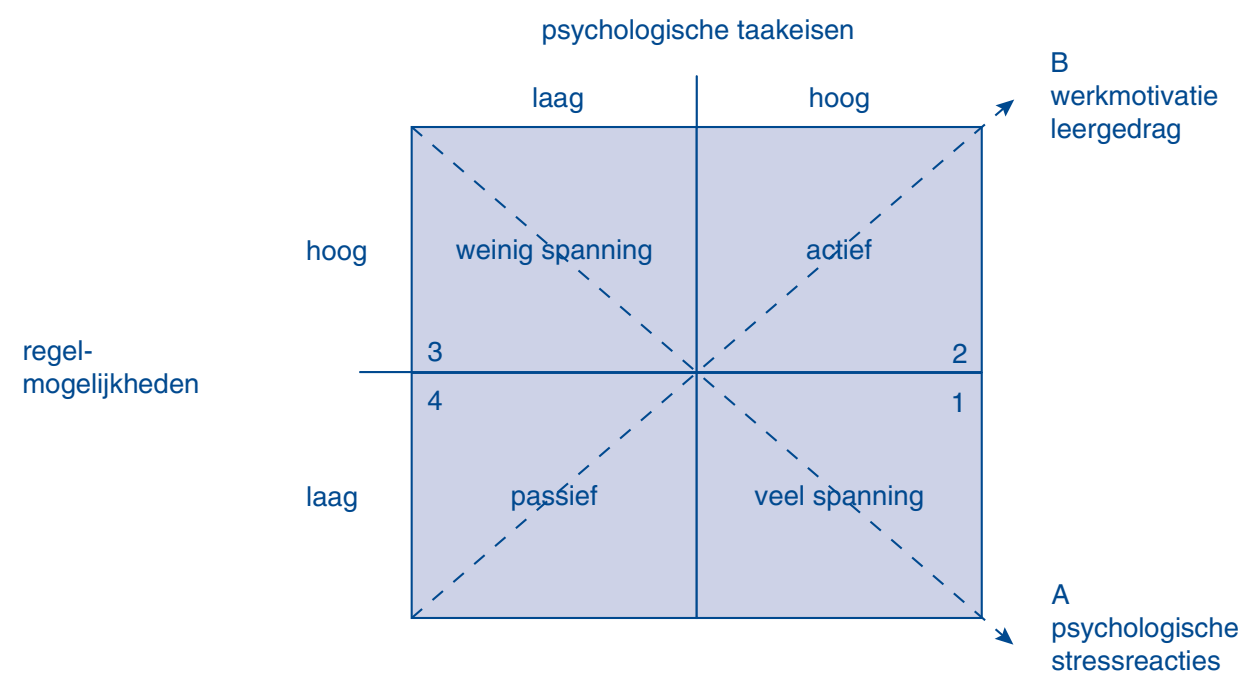

- Figuur 2.2 Demand-Control Model. Bron: Karasek (1979).

Voor dit kwadrant wordt een lager dan gemiddeld niveau van stressreacties voorspeld ('weinig spanning').

De tweede belangrijke veronderstelling van het DC Model (diagonaal B in • Figuur 2.2) is dat persoonlijke groei, leer- en ontplooiingsmogelijkheden zich voordoen indien zowel de taakeisen als de regelmogelijkheden hoog zijn (kwadrant 2: 'actief'). Anders gezegd, het werk stelt hoge eisen, maar de werknemer heeft veel zeggenschap in en over het werk, waardoor de eigen kwaliteiten volledig benut en daardoor ook ontwikkeld kunnen worden. Hier tegenover staat een type werksituatie, waarin taakeisen en regelmogelijkheden beide in geringe mate aanwezig zijn (kwadrant 4). Dit kan tot een afname van arbeidsactiviteiten leiden; een bepaalde mate van passiviteit in de werksituatie die globaal te vergelijken is met een toestand van aangeleerde hulpeloosheid.

Samengevat: psychologische taakeisen en regelmogelijkheden hebben invloed op twee psychische processen. Het ene proces (diagonaal A in $\boldsymbol{0}$ Figuur 2.2) beïnvloedt de (on)gezondheid van de werknemer, terwijl het andere proces (diagonaal B in $\bullet$ Figuur 2.2) de arbeidsmotivatie en het leergedrag van de medewerker beïnvloedt.

Op basis van empirisch onderzoek van Jeffrey Johnson en collega's (Johnson \& Hall, 1988; Johnson, Hall \& Theorell, 1989) is het DC Model in de jaren tachtig uitgebreid met een derde dimensie: sociale ondersteuning in het werk ('workplace social support'). Met het begrip sociale steun wordt hier verwezen naar het bestaan van goede, plezierige relaties met collega's of boven- en ondergeschikten, het kunnen rekenen op anderen, het krijgen van de juiste informatie via anderen, en het verkrijgen van daadwerkelijke hulp, begrip en aandacht wanneer een werknemer in moeilijkheden verkeert. Het onderzoek van Johnson en collega's laat zien dat tekortkomingen in sociale steun de negatieve gezondheidseffecten van werkdruk en regelmogelijkheden versterken.

In dit uitgebreide model, het zogeheten Demand-Control-Support Model (DCS Model), staat de interactie tussen taakeisen, regelmogelijkheden en sociale steun centraal. De diverse combinaties van werkdruk, regelmogelijkheden en sociale steun leveren acht soorten werkomgeving op (zie - Figuur 2.3). De meest ongunstige effecten op gezondheid worden verwacht bij 
psychologische taakeisen

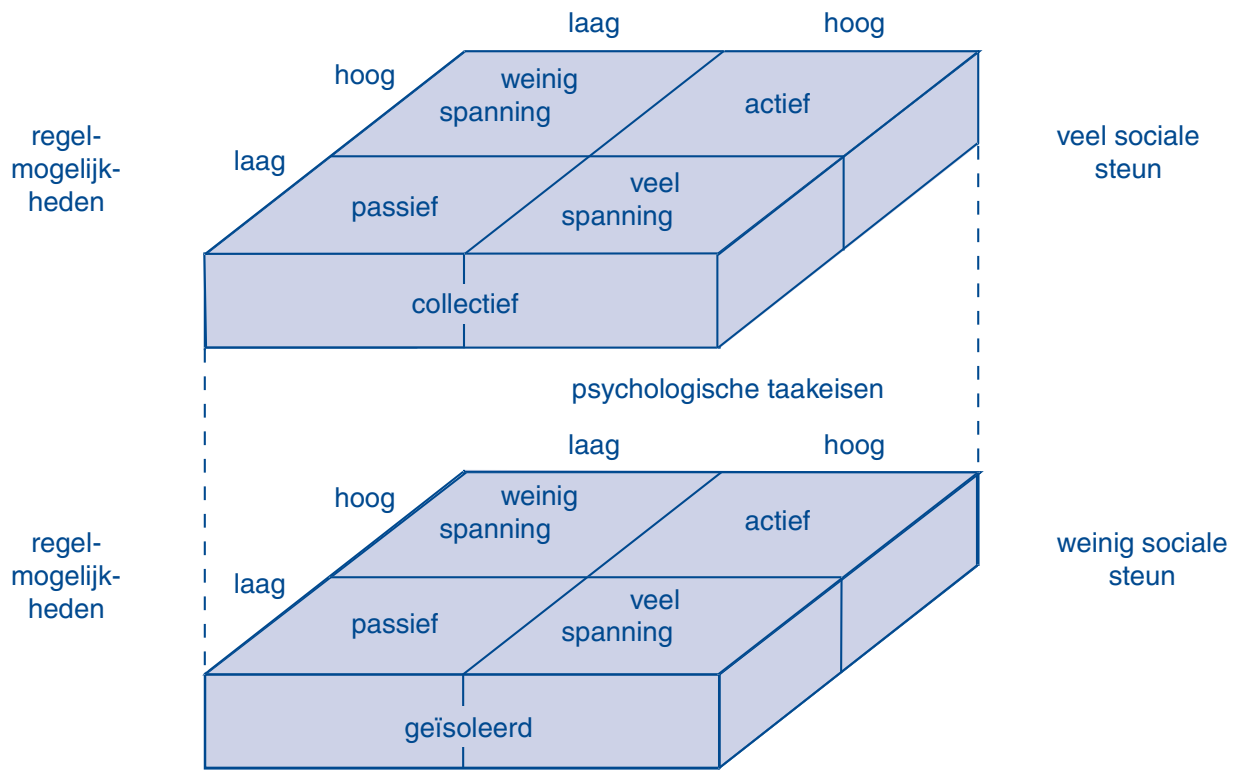

Figuur 2.3 Demand-Control-Support Model. Bron: Johnson en Hall (1988).

een combinatie van hoge taakeisen, weinig regelmogelijkheden en weinig sociale steun: een geïsoleerde werksituatie met veel stressreacties.

\subsubsection{Empirische evidentie}

Sinds de introductie van het DC Model in 1979 zijn er honderden empirische studies met het model als kader uitgevoerd (zie $\downarrow$ www.workhealth.org en $\downarrow$ www.unhealthywork.org). Ook hebben Karasek en collega's veel onderzoekers geïnspireerd en gestimuleerd om de relatie tussen psychosociale werkkenmerken en gezondheid aan de hand van het model te bestuderen. Daarbij wordt vaak gebruikgemaakt van de Job Content Questionnaire (JCQ), een meetinstrument voor de belangrijkste constructen van het model. Deze onderzoekingen kunnen opgedeeld worden in drie soorten empirische studies (De Jonge \& Kompier, 1997).

1. Epidemiologische onderzoekingen, voornamelijk gericht op langetermijneffecten van taakeisen en regelmogelijkheden op de gezondheid. Deze studies, meestal grootschalige bevolkingsonderzoeken, zijn voornamelijk gericht op het voorspellen van hart- en vaatziekten. Zo toonden Johnson en Hall (1988) aan dat voor werknemers in een werksituatie met hoge taakeisen, weinig regelmogelijkheden en weinig sociale ondersteuning het relatieve risico op hart- en vaatziekten meer dan tweemaal zo groot was dan voor werknemers in een situatie gekenmerkt door lage taakeisen, veel regelmogelijkheden en veel sociale ondersteuning. In het bijzonder sociale ondersteuning op het werk bleek een belangrijk aandeel te hebben in het voorspelde risico.

2. Studies gebaseerd op specifieke homogene of heterogene beroepsgroepen. Dit zijn zowel cross-sectionele als longitudinale onderzoeken naar allerlei typen stressreacties, zoals 
affectieve, cognitieve, gedragsmatige, fysieke en fysiologische uitkomsten. Uit een overzichtsstudie van Van der Doef en Maes (1999) blijkt dat er relatief veel ondersteuning is voor de hypothese dat werknemers in een baan die gekenmerkt wordt door enerzijds hoge taakeisen en anderzijds weinig regelmogelijkheden en/of weinig sociale ondersteuning, de meeste klachten rapporteren. Het empirische bewijs voor het interactie- of buffereffect van regelmogelijkheden en sociale steun op de relatie tussen hoge taakeisen en stressreacties is echter minder consistent. Vaak worden enkel directe verbanden van (hoge) taakeisen, (weinig) regelmogelijkheden en (weinig) sociale steun met gezondheidsklachten gevonden. De Lange en collega's (2003) hebben een overzicht gepubliceerd van longitudinale studies naar het model. Hieruit bleek dat er bescheiden empirische steun voor de stresshypothese (diagonaal A) van het model bestaat. In acht van de negentien longitudinale studies (ofwel $42 \%$ ) werd de combinatie van hoge werkdruk en weinig regelmogelijkheden gevonden. Ook concludeerden zij dat heterogene studies (dat wil zeggen studies onder meerdere beroepsgroepen) niet meer ondersteuning voor het model bieden dan homogene studies (onder een enkele groep werknemers).

3. Onderzoekingen die het kortetermijneffect van taakeisen en regelmogelijkheden onder de loep nemen. Het betreft hier monitorstudies of (quasi-)experimenten om directe veranderingen in fysiologische parameters (zoals cortisol en adrenaline - zie $>$ H. 3 en $>$ H. 4) te kunnen vaststellen. Ganster en Mayes (1988) vonden bijvoorbeeld een significante interactie tussen taakeisen en regelmogelijkheden met betrekking tot het adrenalineniveau (zie ook H. 4). Het hebben van veel regelmogelijkheden bleek de positieve relatie tussen taakeisen en adrenalineniveau te verminderen.

Er kunnen ten minste twee belangrijke conclusies uit de veelheid aan onderzoekingen getrokken worden. De eerste conclusie is dat de epidemiologische studies de meeste ondersteuning bieden voor het DC(S) Model, en dan vooral voor de stresshypothese (diagonaal A). Dit zijn veelal grootschalige studies waarin gemakkelijker diverse effecten aan te tonen waren vanwege de grote 'power' van het onderzoek (zie ook $\neg$ H. 12). De tweede hypothese van het model (de activiteitshypothese; diagonaal B) krijgt minder aandacht in de literatuur en is nauwelijks onderzocht (zie ook Taris, Kompier \& Wielenga-Meijer, 2006). Een mogelijke reden hiervoor is dat de grootste belangstelling voor beide modellen uit de epidemiologische hoek kwam, met hart- en vaatziekten als de belangrijkste effectmaat. Dit soort aandoeningen was - en is nog steeds - de 'number one killer' in de geïndustrialiseerde landen.

Een tweede conclusie is dat de veronderstelling dat vooral de combinatie van taakeisen, regelmogelijkheden en sociale steun gepaard gaat met sterkere reacties (bijv. meer gezondheidsklachten of juist meer actief leergedrag) niet vaak ondersteund wordt. Met andere woorden, in plaats van interactie-effecten wordt meestal gevonden dat de drie componenten afzonderlijk een effect hebben op uitkomstvariabelen.

\subsubsection{Kanttekeningen}

In de loop van de jaren zijn enkele inhoudelijke en methodologische kanttekeningen bij het DC(S) Model geplaatst. We laten de drie belangrijkste kritiekpunten de revue passeren. Ten eerste heeft de conceptualisering en operationalisering van zowel taakeisen als regelmogelijkheden veel stof doen opwaaien. Zo zijn de begripsomschrijvingen van de werkkenmerken niet eenduidig door Karasek geformuleerd. Ook geven diverse onderzoekers aan dat de verschillende gebruikte schalen binnen de Job Content Questionnaire (JCQ) niet alleen taakeisen of 
regelmogelijkheden weerspiegelen, aangezien bij het merendeel van de gebruikte operationaliseringen meerdere werkkenmerken bij de constructen betrokken worden (bijv. De Jonge \& Kompier, 1997). Overigens is de Nederlandse versie van de JCQ te verkrijgen via $\boldsymbol{} w w w$. psychischenwerk.nl.

Ten tweede staat in het model de interactie tussen de diverse werkkenmerken centraal (zie ook H. 10). De aard van de interactie is vreemd genoeg nooit goed uitgewerkt. Karasek (1989) omzeilt dit probleem door te stellen dat de aard van de interactie primair een praktische betekenis kent, namelijk dat welbevinden en gezondheid verklaard kunnen worden door verschillende combinaties van de werkkenmerken. Dit hoeft dus niet per se een statistische interactie te zijn. Volgens Kasl (1996) is het interactie-effect binnen de DC-benadering echter op twee manieren uit te leggen:

- Regelmogelijkheden en sociale steun fungeren als moderator- of buffervariabelen, in die zin dat veel regelmogelijkheden of veel sociale steun het negatieve effect van takeisen op de gezondheid verminderen.

- Er is sprake van synergie, want zowel weinig regelmogelijkheden en weinig steun als hoge taakeisen hebben een negatieve uitwerking op de gezondheid, maar hun onderlinge combinatie heeft een verhoogde werking tot gevolg (die groter is dan de som van de afzonderlijke effecten).

De veronderstelde interactie-effecten van taakeisen, regelmogelijkheden en sociale steun worden trouwens ook niet vaak gevonden. En als ze gevonden worden, zijn ze relatief zwak en soms niet in de richting die het model veronderstelt. Hieraan lijken enkele methodische problemen ten grondslag te liggen, vooral de manier waarop de interactie tussen de verschillende werkkenmerken in empirisch onderzoek wordt geoperationaliseerd (Van Vegchel, De Jonge \& Landsbergis, 2005). Allereerst dient de wiskundige formulering van deze interactie in overeenstemming te zijn met de theoretische gedachten die men heeft over de relatie tussen de verschillende werkkenmerken in de voorspelling van gezondheid. Analoog aan de assumpties van het DC(S) Model lijkt een multiplicatieve interactieterm (te weten met product van taakeisen, regelmogelijkheden en sociale steun) de meest geijkte manier om het interactie-effect tussen taakeisen, regelmogelijkheden en sociale steun vast te stellen (Van Vegchel e.a., 2005). Toch worden ook vaak andere interactieformuleringen gebruikt om het model te toetsen (bijv. ratio's en verschilscores), met tegenstrijdige bevindingen als gevolg. Daarnaast betreft het hier de specificiteit waarmee de centrale concepten uit het DC(S) Model worden gemeten. Onderzoek van Van Vegchel e.a. (2005) toont aan dat de kans op het vinden van interactie-effecten substantieel groter is wanneer meer specifiekere maten van de diverse werkkenmerken gebruikt worden in vergelijking met meer algemenere en globale maten.

Ten derde is een van de veronderstellingen van het DC(S) Model dat situationele kenmerken van het werk bepalend zijn voor de gezondheid en het welbevinden van de taakuitvoerders. Individuele verschillen tussen mensen (bijv. persoonskenmerken) worden door de makers van het model niet als belangrijk voor de effecten van werkkenmerken beschouwd. De juistheid van deze veronderstelling kan echter in twijfel worden getrokken. Er verschijnt steeds meer empirisch onderzoek waaruit blijkt dat het al dan niet vinden van interactie-effecten tussen taakeisen en regelmogelijkheden wel degelijk afhangt van de aan- of afwezigheid van bepaalde persoonskenmerken, zoals hanteringsgedrag (coping), beheersingsoriëntatie ('locus of control') en Type-A/B-gedrag (zie ook $>$ H. 15).

Zo bleek het interactie-effect van hoge taakeisen en weinig regelmogelijkheden op gezondheidsklachten van werknemers alleen te bestaan, wanneer deze werknemers op een actieve wijze met problemen omgingen. Niet-actieven hadden bij een hoge werkdruk altijd veel 
gezondheidsklachten, ongeacht de hoeveelheid regelmogelijkheden (zie Furda, 1995; De Rijk e.a., 1998). Verder bleek uit een longitudinale studie onder Japanse werknemers dat het bufferende effect van regelmogelijkheden enkel optrad indien werknemers op kortere termijn op actieve wijze met problemen omgingen (Shimazu, De Jonge \& Irimajiri, 2008). Op iets langere termijn bleek dit effect niet meer aanwezig te zijn. De resultaten van deze studies suggereren dat hoge taakeisen en weinig regelmogelijkheden negatieve gezondheidsgevolgen hebben voor alle werknemers, doch voor de ene werknemer meer dan voor de andere, afhankelijk van zijn of haar persoonskenmerken.

\subsection{Vitaminemodel}

\subsubsection{Inhoud}

De Engelse psycholoog Peter Warr (1987; 2007) vergelijkt de invloed van omgevingskenmerken ('environmental features') op de mentale gezondheid van het individu met die van vitaminen op het menselijk lichaam. Zijn 'Vitamin Model' (Vitaminemodel) is opgebouwd aan de hand van vier elementen:

1. effecten van omgevingskenmerken op de mentale gezondheid;

2. categorisering van omgevingsfactoren in een aantal typen;

3. multidimensionaliteit van het welbevinden;

4. wisselwerking tussen persoon en omgeving.

Het Vitaminemodel is een breed opgezet en dito toepasbaar model dat ook opgaat buiten de arbeidssituatie (bijv. bij werkloosheid). Niet voor niets spreekt Warr over omgevingskenmerken in plaats van werkkenmerken. Hier zullen we ons echter tot de werksituatie beperken.

Warr $(1987,2007)$ veronderstelt dat werkkenmerken de geestelijke gezondheid op analoge wijze beïnvloeden als vitaminen de lichamelijke gezondheid. Men zou dus van 'arbeidsvitaminen' kunnen spreken (De Jonge, Schaufeli \& Furda, 1995). De aanwezigheid van werkkenmerken heeft in eerste instantie een positieve invloed op de werknemer (segment A in - Figuur 2.4). Een verdere toename levert geen extra rendement meer op voor de geestelijke gezondheid: het 'mid-range'-plateau is bereikt (segment B in - Figuur 2.4). Hoge 'doseringen' van werkkenmerken kunnen tot twee typen effecten leiden. Sommige zullen geen extra invloed op de werknemer hebben, maar een 'Constant Effect' (CE-patroon), terwijl andere een negatieve uitwerking hebben, ofwel een 'Additional Decrement' (AD-patroon). In dit laatste geval wordt een kromlijnig of curvelineair effect verondersteld van werkkenmerken op de geestelijke gezondheid (segment $\mathrm{C}$ in $\mathbf{0}$ Figuur 2.4).

Op basis van een literatuuronderzoek onderscheidt Warr $(1987,2007)$ negen werkkenmerken, die doorgaans als determinanten van geestelijke gezondheid worden opgevat. • Tabel 2.1 vat deze psychologische 'arbeidsvitaminen' samen.

Volgens het Vitaminemodel kunnen de - extreme - effecten van deze werkkenmerken in twee categorieën verdeeld worden. Deze categorisering omvat het tweede element van het model. Drie werkkenmerken gedragen zich analoog aan het CE-patroon, terwijl de effecten van de overige zes het $\mathrm{AD}$-patroon volgen. Voor autonomie bijvoorbeeld wordt een $\mathrm{AD}$-patroon verondersteld. Te veel autonomie in het werk kan schadelijk zijn voor de geestelijke gezondheid van de werknemer, omdat dit gepaard kan gaan met gebrek aan structuur en een te grote mate van verantwoordelijkheid. Voor de beschikbaarheid van geld wordt echter een CE-patroon verondersteld. Het opstrijken van grote sommen geld zal na een bepaald punt geen extra effect 


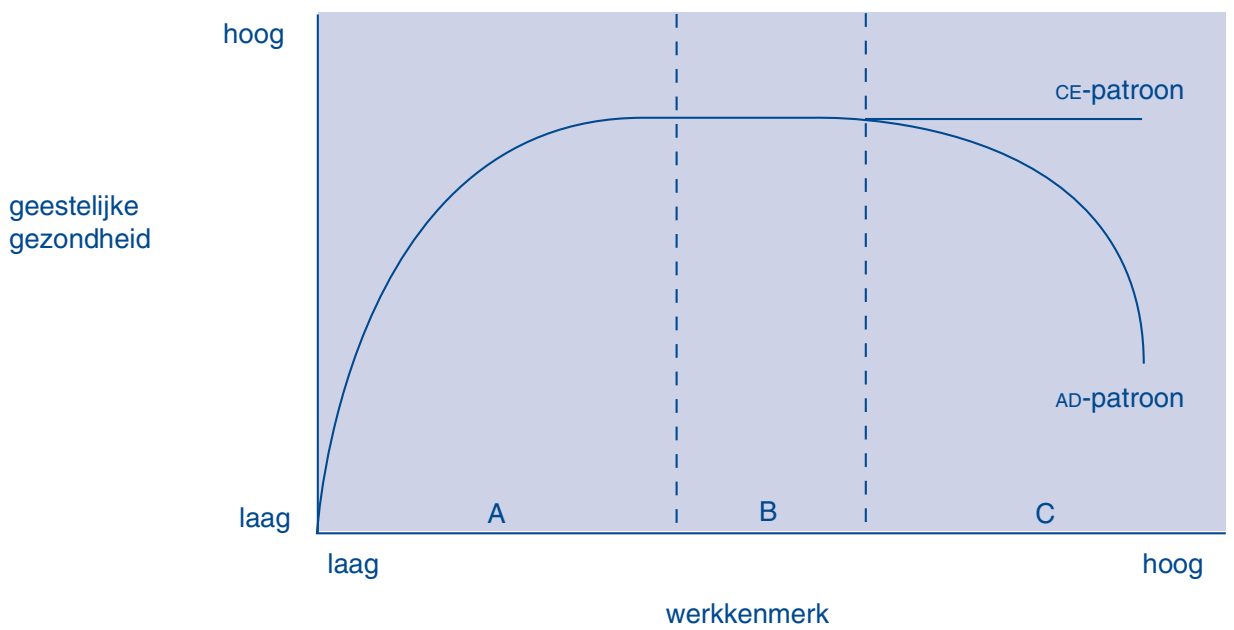

- Figuur 2.4 Vitaminemodel. Bron: Warr (1987).

meer hebben op de geestelijke gezondheid van de werknemer, aangezien een verzadigingspunt bereikt is.

De kern van de geestelijke gezondheid wordt volgens Warr $(1987,2007)$ gevormd door affectief welbevinden ('affective well-being'), het derde element van het model. Affectief welbevinden is een multidimensionaal begrip, waarvan de elementen volgens Warr kunnen worden afgebeeld met behulp van een assenstelsel, bestaande uit vier centrale assen (zie - Figuur 2.5).

De beide orthogonale assen worden gevormd door de dimensies lust ('pleasure') en activatie ('arousal'). De beide diagonale assen hebben achtereenvolgens betrekking op de dimensies gespannen-rustig ('anxious-comfortable') en neerslachtig-enthousiast ('depressed-actively pleased'). Warr beschouwt de horizontale as en beide diagonale assen als de belangrijkste dimensies van het welbevinden. De activatiedimensie wordt niet als specifieke indicator van affectief welbevinden beschouwd en is dan ook niet voorzien van labels aan beide uiteinden. De negatieve aspecten van affectief welbevinden worden in de linkerhelft van de figuur weergegeven, de positieve in de rechterhelft. - Figuur 2.5 is ovaal omdat de lustdimensie als indicator voor affectief welbevinden belangrijker wordt geacht dan de activatiedimensie.

Voorts maakt Warr $(1987,2007)$ een onderscheid tussen algemene ('context-free') geestelijke gezondheid en arbeidsgebonden ('job-related') geestelijke gezondheid. Toegepast op de werksituatie weerspiegelen de drie assen in - Figuur 2.5 onder andere: de mate van arbeidstevredenheid (as 1), werkgerelateerde spanningen (as 2) en burnout (as 3 ).

Het vierde en laatste element van het model heeft betrekking op de wisselwerking tussen persoon en omgeving. Vier categorieën van persoonskenmerken worden onderscheiden:

1. demografische kenmerken (bijv. leeftijd en geslacht);

2. vaardigheden (bijv. intellectuele en sociale vaardigheden);

3. waarden (bijv. specifieke voorkeuren en motieven);

4. basale mentale gezondheid (bijv. tot uitdrukking komend in neuroticisme en zelfvertrouwen).

De invloed van deze persoonskenmerken is tweeledig. Allereerst is het mogelijk dat een persoonskenmerk directe invloed heeft op de geestelijke gezondheid, onafhankelijk van de omgevingskenmerken. Ze kunnen echter ook een indirect effect hebben, dat tot uitdrukking komt 
Tabel 2.1 De negen werkkenmerken van het Vitaminemodel

\begin{tabular}{|l|l|}
\hline CE-werkkenmerken & AD-werkkenmerken \\
\hline salaris & autonomie \\
\hline veiligheid & werkdruk \\
\hline betekenisvolheid & sociale ondersteuning \\
\hline & gebruik van vaardigheden \\
\hline & afwisseling in het werk \\
\hline & feedback \\
\hline
\end{tabular}

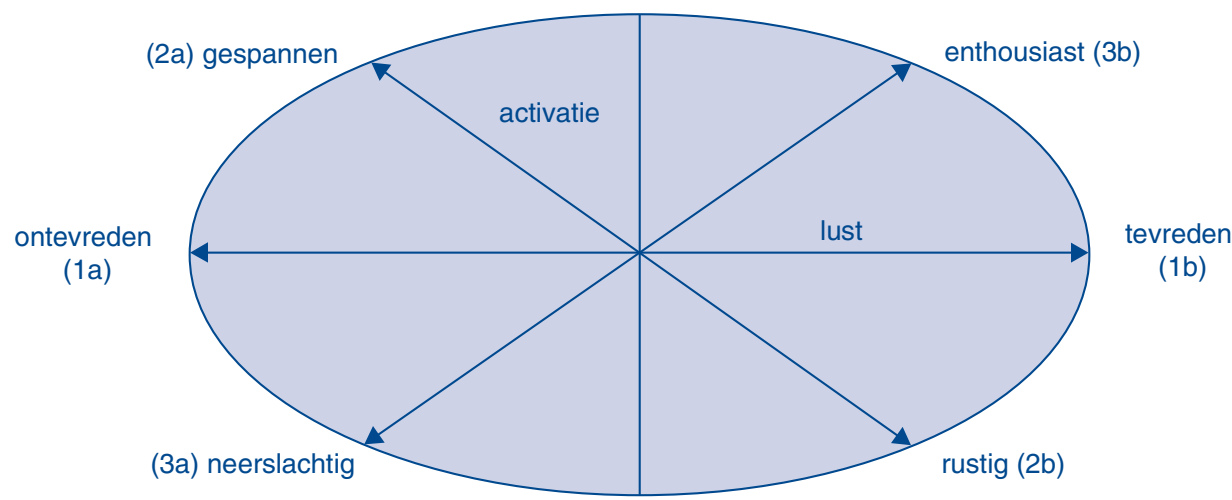

Figuur 2.5 Affectief welbevinden. Bron: Warr (1987).

in een mediërend of modererend effect op het verband tussen omgevingskenmerken en geestelijke gezondheid (zie $>$ H. 10). Warr (2007) veronderstelt dat werkkenmerken een sterker effect zullen hebben op het welbevinden van werknemers die een bijpassend persoonskenmerk bezitten. Mensen met een bepaalde waardeoriëntatie zullen eerder werksituaties zoeken die overeenkomen ('matchen') met deze oriëntatie. Daarnaast zullen zij eerder de desbetreffende werkkenmerken waarderen of zich juist slechter voelen als deze kenmerken niet beschikbaar zijn. Zo zal een werknemer met een grote behoefte aan ontwikkeling sterker reageren (bijv. in termen van meer arbeidstevredenheid) op een werksituatie waarin autonomie en afwisseling aanwezig zijn dan een werknemer die deze behoefte niet heeft.

\subsubsection{Empirische evidentie}

Het Vitaminemodel is nog altijd niet in zijn totaliteit getoetst. Wel geeft Warr (2007) een gedegen overzicht van empirisch onderzoek, waarin hij aannemelijk maakt dat de negen werkkenmerken zich conform het Vitaminemodel gedragen. Het gaat hierbij veelal om een post-hocredenering, die voornamelijk steunt op onderzoek naar rechtlijnige verbanden tussen werkkenmerken en geestelijke gezondheid. In de loop der jaren zijn in enkele cross-sectionele 
deelstudies de door het Vitaminemodel gepostuleerde kromlijnige patronen getoetst (De Jonge \& Schaufeli, 1998; De Jonge e.a., 2000; Jeurissen \& Nyklicek, 2001; Xie \& Johns, 1995; Warr, 1990). Over het algemeen zijn de resultaten van deze empirische studies echter niet eenduidig en worden ook niet in longitudinaal onderzoek gerepliceerd (Rydstedt, Ferrie \& Head, 2006). Taakeisen en autonomie lijken nog het meest conform de voorspellingen van het model samen te hangen met de geestelijke gezondheid van werknemers, terwijl dit niet het geval is voor sociale ondersteuning.

Daarnaast heeft geen enkele van bovengenoemde studies rekening gehouden met de mogelijk multivariate wijze waarop de negen werkkenmerken kunnen samenhangen met het werkgerelateerde welbevinden. Alleen De Jonge en Schaufeli (1998) hebben hiertoe een bescheiden poging gewaagd, door drie werkkenmerken simultaan te koppelen aan drie indicatoren van welbevinden. Uit deze cross-sectionele studie kwamen diverse kromlijnige verbanden naar voren van werkdruk, autonomie en sociale steun in de voorspelling van arbeidstevredenheid, burnout en gevoelens van angst. Voorts zijn er nog geen longitudinale studies naar het model uitgevoerd, waardoor er nog geen uitspraken gedaan kunnen worden met betrekking tot de causaliteit van de gevonden verbanden.

Boer, De Jonge en Hamers (2003) onderzochten het modererende effect van bijpassende persoonskenmerken op de relatie tussen werkkenmerken en welbevinden. Analoog aan de ideeën van Warr (1987) werd gevonden dat variaties in werkkenmerken meer effect hadden op het welbevinden van werknemers die een bijpassend persoonskenmerk bezaten, dan op dat van werknemers die dit bijpassende persoonskenmerk niet bezaten. Uit de resultaten bleek bijvoorbeeld dat de positieve relatie tussen autonomie en werktevredenheid sterker was naarmate werknemers een grote behoefte aan autonomie hadden.

\subsubsection{Kanttekeningen}

Een kanttekening bij het Vitaminemodel betreft de ietwat willekeurige indeling van de negen werkkenmerken in AD- of CE-effecten. Het is maar de vraag of een kenmerk als feedback een kromlijnig effect met de gezondheid heeft, en of veel extra salaris en veiligheid geen meerwaarde hebben voor iemands welbevinden(en dus een verzadigingspunt kennen). Dit type hypothesen vraagt om meer theoretisch en empirisch onderzoek. Een andere kanttekening is dat meer onderzoek nodig is naar de rol van bijpassende persoonskenmerken in het Vitaminemodel (zie Boer e.a., 2003).

\subsection{Effort-Reward Imbalance Model}

\subsubsection{Inhoud}

Het Effort-Reward Imbalance Model (ERI Model) is afkomstig van de in Duitsland werkende Zwitserse medisch socioloog Johannes Siegrist en collega's (Siegrist e.a., 1986; Siegrist, 1996). Het ERI Model is ontwikkeld vanuit de gedachte dat de werkrol een belangrijke schakel vormt tussen de persoonlijke behoeften van het individu en de maatschappelijke structuur. Het ERI Model legt daarom meer nadruk op de beloningsstructuur van het werk dan op de controlemogelijkheden van de werknemer in het werk, zoals in het DC(S) Model. Het ERI Model veronderstelt namelijk dat inspanningen op het werk ('job-related efforts') deel uitmaken van een sociaal uitwisselingsproces, waar normaliter in onze maatschappij een aantal materiële en 


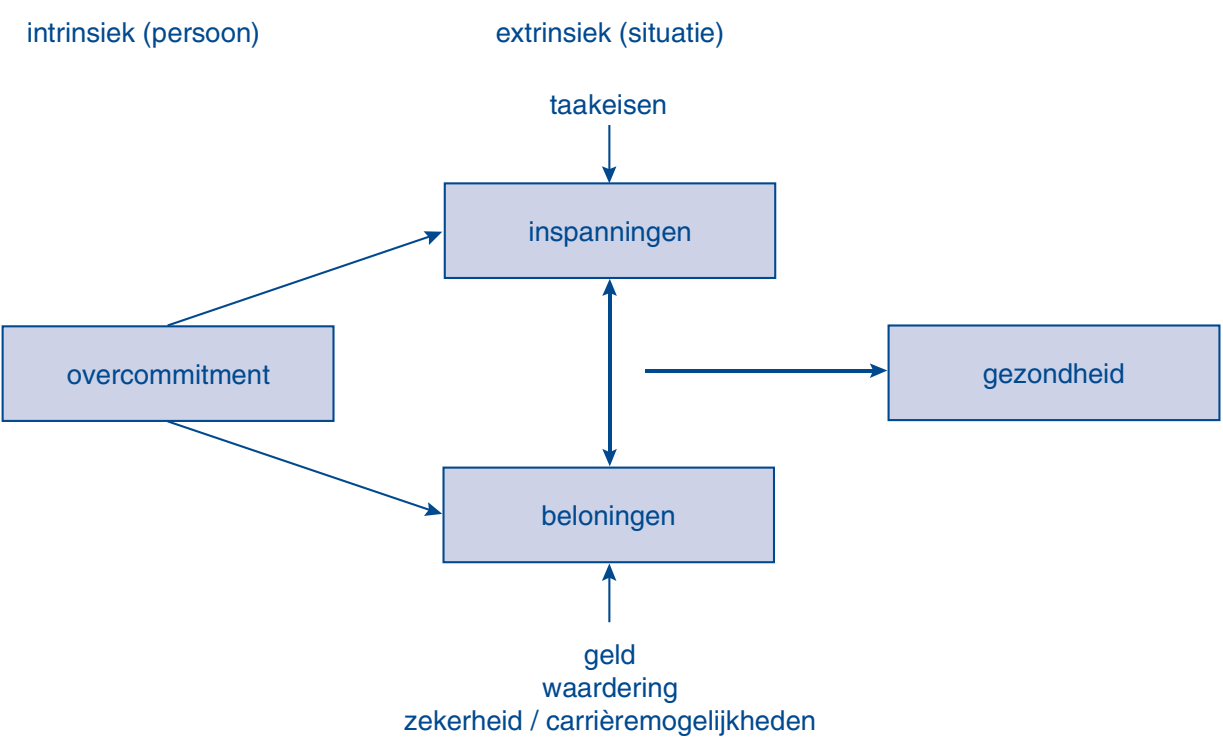

- Figuur 2.6 Effort-Reward Imbalance Model. Bron: Siegrist (2001).

immateriële beloningen ('occupational rewards') tegenover staan. Onder inspanningen worden allerlei typen taakeisen gerekend, zoals tijdsdruk, fysieke inspanning en taakinterrupties. Onder beloningen wordt in het model verstaan:

- geld (bijv. een adequaat salaris);

- waardering (bijv. respect en ondersteuning);

- zekerheid en carrièremogelijkheden (bijv. promotiekansen, baanzekerheid en behoud van status).

Volgens het model wordt het optreden van stressreacties bepaald door hoge inspanning, gepaard gaand met een lage beloning ('high effort, low reward-imbalance'). Deze disbalans (hoge inspanning versus lage beloning) kan leiden tot allerlei stressreacties, zoals hart- en vaataandoeningen, gezondheidsklachten, ontevredenheid en arbeidsverzuim (zie $\bullet$ Figuur 2.6).

Het hebben van een veeleisende, onzekere baan zonder goed arbeidscontract, een redelijk salaris of kansen op promotie, is een voorbeeld van een stressvolle disbalans. In overeenstemming met psychologische theorieën over zelfwaardering ('self-esteem') en eigen effectiviteit ('self-efficacy'; Bandura, 1997) veronderstelt het ERI-Model dat herhaalde ervaringen van 'effort-reward imbalance' iemands gevoel van beheersing van de situatie ('feeling of mastery') op den duur kunnen verzwakken. Ook accepteren werknemers eerder een stressvolle disbalans op de kortere termijn, in de veronderstelling dat dit een strategische investering is voor een juiste balans tussen inspanningen en beloningen op de langere termijn (in het kader van een beter carrièreperspectief).

Verder veronderstelt het model dat persoonskenmerken een modererende rol spelen in de relatie tussen werk en gezondheid. In het ERI Model wordt in het bijzonder aandacht besteed aan een te sterke betrokkenheid bij het werk: 'overcommitment' (Siegrist, 2001). Dit wordt gekarakteriseerd door de volgende kenmerken: streberig gedrag, moeite om het werk van zich af te zetten (zich onder meer uitend in een sterke werkbetrokkenheid), en behoefte aan goedkeuring en waardering. Het construct lijkt vooral gerelateerd aan kernaspecten van 
Type-A-gedrag (bijv. overdreven werkbetrokkenheid, gedrevenheid en wedijver), dat sterk geassocieerd is met verhoogde opwinding ('arousal') in veeleisende situaties (zie $>$ H. 15) en met workaholisme, dat wil zeggen, een combinatie van hard werken en innerlijke gedrevenheid (zie $>$ H. 18). Werknemers die gekenmerkt worden door 'overcommitment', verrichten (vinden zij zelf) doorgaans een grote hoeveelheid inspanning die (in hun ogen) niet voldoende beloond wordt. Volgens het ERI Model heeft dit type werknemers een groter risico op het ervaren van een stressvolle disbalans (hoge inspanning versus lage beloning), wat (op termijn) tot meer gezondheidsklachten kan leiden. Om de kerncomponenten van het ERI Model te meten, is een instrument ontwikkeld, de zogenoemde ERI-Questionnaire (ERI-Q). Dit meetinstrument is in diverse talen beschikbaar, waaronder in het Nederlands (zie $\mathbf{w w w}$. psychischenwerk.nl).

\subsubsection{Empirische evidentie}

Er is veel empirisch onderzoek naar het ERI Model gedaan en het aantal gepubliceerde studies groeit nog steeds. Hieruit blijkt dat de combinatie van hoge inspanningen en lage beloningen in het werk inderdaad een risicofactor is voor hart- en vaataandoeningen en voor een slechte ervaren gezondheid, inclusief psychische aandoeningen en arbeidsverzuim (zie overzichtsstudies van Van Vegchel, De Jonge, Bosma \& Schaufeli, 2005 en Tsutsumi \& Kawakami, 2004). In totaal gaat het om een kleine honderd studies die inmiddels uitgevoerd zijn in Europa, Amerika (Verenigde Staten) en Azië (Japan, China en Taiwan), zoals vermeld op $\triangleright$ www.uniduesseldorff.de/medicalsociology. Zo bleek de kans op een hartinfarct voor werknemers in een 'high effort, low reward-imbalance'-situatie tot negenmaal hoger te zijn dan voor personen in de tegenovergestelde situatie (Van Vegchel e.a., 2005). Ook blijkt in het algemeen dat het voorspellend vermogen van het ERI Model groter is voor individuen die gekenmerkt worden door 'overcommitment' (zie ook $>$ H. 4). Er zijn echter ook enkele studies die dit effect van 'overcommitment' niet konden aantonen of zelfs tegenovergestelde resultaten vonden (bijv. Van Vegchel e.a., 2001).

\subsubsection{Kanttekeningen}

Evenals bij het DC(S) Model hebben de operationaliseringen van de constructen van het ERI Model tot kritiek geleid. Zo blijkt de inspanningsschaal te bestaan uit zes items met een sterk uiteenlopende inhoud, zoals tijdsdruk, fysieke inspanning, verantwoordelijkheid en overwerk. Deze verscheidenheid binnen een enkele schaal maakt het onduidelijk welk type inspanning belangrijk is voor de disbalans tussen inspanningen en beloningen bij het voorspellen van gezondheidsklachten.

Een andere kritische noot kan geplaatst worden bij de gebruikte antwoordcategorieën van de inspannings- en beloningsschalen (Tsutsumi, 2004; De Jonge e.a., 2008). Er worden twee typen antwoordcategorieën gebruikt: allereerst moet een werknemer aangeven of de desbetreffende situatie in het werk aanwezig is, en daarna moet hij of zij aangeven hoe stressvol deze situatie is. Deze wijze van bevragen blijkt niet erg valide en werkt tevens misclassificaties en non-respons in de hand. Tsutsumi (2004) heeft daarom voorgesteld om de tweedeling terug te brengen naar één antwoordcategorie (waarin beide antwoordcategorieën geïntegreerd zijn tot een enkele vijfpuntsschaal), hetgeen in de meest recente versie van de ERI-vragenlijst ook door Siegrist is overgenomen (op de vragen via $\downarrow$ www.psychischenwerk.nl). 
Een derde en laatste kritiekpunt geldt het empirisch bewijs voor het ERI Model. In een relatief groot aantal studies wordt het model niet in zijn totaliteit onderzocht. Het gaat vaak om een combinatie van twee van de drie onafhankelijke maten, bijvoorbeeld de combinatie van 'overcommitment' en beloningen in de voorspelling van aandoeningen en klachten (zie Van Vegchel e.a., 2005). Dat dit type onderzoek minder bijdraagt aan bewijsvorming rond het ERI Model behoeft geen verder betoog.

\subsection{Job Demands-Resources Model}

\subsubsection{Inhoud}

Het Job Demands-Resources Model (JD-R Model) ofwel in de Nederlandse vertaling het Werkstressoren Energiebronnen Burnout Model (WEB Model), is eind jaren 1990 ontwikkeld door de A\&O-psychologen Evangelia Demerouti, Arnold Bakker en Wilmar Schaufeli (Bakker, Schaufeli \& Demerouti, 1999; Demerouti, Bakker, Nachreiner \& Schaufeli, 2001). Het JD-R Model gaat uit van drie veronderstellingen (Bakker \& Demerouti, 2007). De eerste veronderstelling is dat elke beroepsgroep weliswaar zijn eigen specifieke risicofactoren voor stress en motivatie kent, maar dat deze onder te verdelen zijn in twee brede categorieën: taakeisen ('job demands') ofwel te leveren inspanningen, en energiebronnen ('job resources') ofwel beschikbare mogelijkheden in het werk of in de werksituatie. Voorbeelden van taakeisen zijn werkdruk, taakinterrupties, rolproblemen en emotioneel veeleisende klanten. Wanneer hoge taakeisen zich bij voortduring voordoen terwijl er onvoldoende mogelijkheid voor herstel aanwezig is, zullen deze de gedaante van werkstressoren aannemen. Zo vormen ze aanleiding voor negatieve reacties, zoals burnout (zie $\checkmark$ H. 17). Energiebronnen zijn te lokaliseren op het niveau van de organisatie (bijv. loopbaanmogelijkheden), interpersoonlijke relaties (bijv. steun van collega's), de organisatie van het werk (bijv. participatie in besluitvorming) en de taak (bijv. feedback).

In de tweede plaats veronderstelt het JD-R Model twee parallelle processen (zie - Figuur 2.7). In het eerste, energetische, stressproces leiden veeleisende aspecten van het werk tot een voortdurende aantasting van de energiereserves en daarmee op de lange duur tot mentale uitputting (burnout). Op zijn beurt kan dit resulteren in negatieve uitkomsten zoals gezondheidsklachten en arbeidsverzuim. Het tweede proces is motivationeel van aard en veronderstelt dat de aanwezigheid van energiebronnen, vanwege hun intrinsiek motivationele kwaliteiten, zal leiden tot bevlogenheid. Bevlogenheid is een positieve psychologische toestand die wordt gekenmerkt door vitaliteit, toewijding en absorptie (zie $>$ H. 17). Dit kan vervolgens weer resulteren in positieve uitkomsten, zoals organisatiebetrokkenheid en een goede arbeidsprestatie. Samengevat: het JD-R Model veronderstelt dat burnout en bevlogenheid een mediërende rol spelen in respectievelijk een stress- en motivatieproces.

Zoals blijkt uit - Figuur 2.7 veronderstelt het model ook een aantal dwarsverbanden tussen beide processen. Zo zal de afwezigheid van energiebronnen stressreacties bevorderen, welke zullen leiden tot minder positieve uitkomsten. Ook blijkt de aanwezigheid van bepaalde taakeisen motivationele processen te kunnen bevorderen. Dit is met name het geval voor taakeisen die een uitdading in plaats van een bedreiging vormen, zoals de mentale eisen die het werk stelt. Verder zijn taakeisen en energiebronnen negatief gerelateerd. Immers, wanneer taakeisen hoog zijn zullen er in het algemeen weinig energiebronnen aanwezig zijn, en vice versa. Ten slotte zijn stressreacties en bevlogenheid negatief aan elkaar gerelateerd (zie H. 17). 


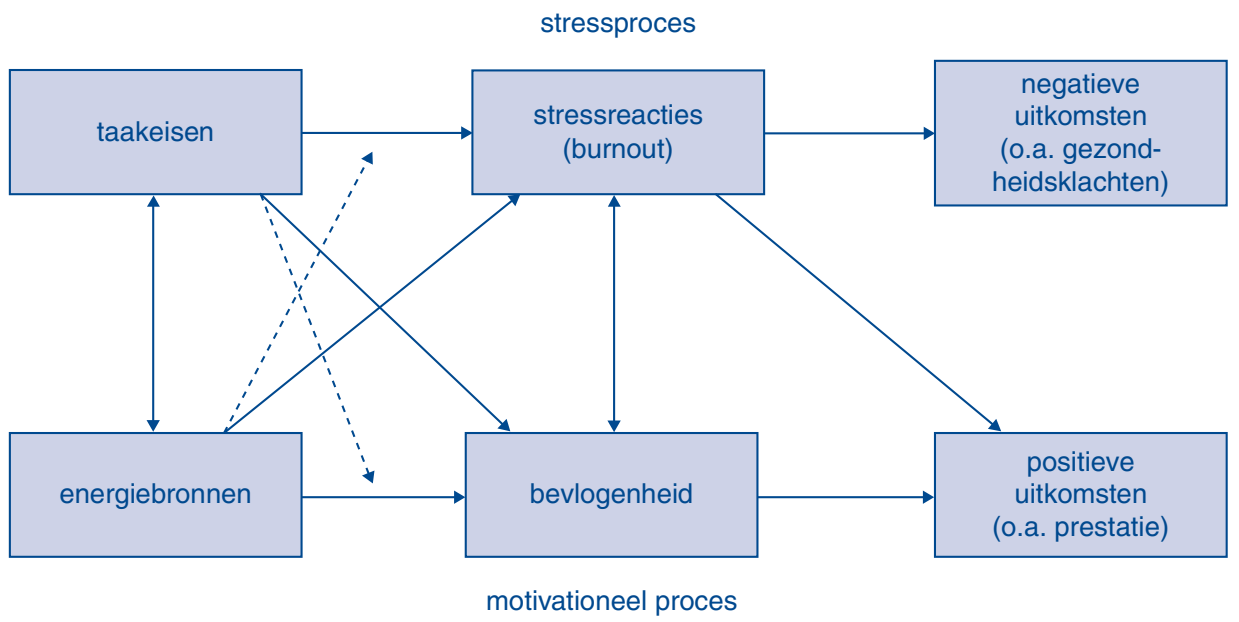

- Figuur 2.7 Job Demands-Resources Model.

De derde veronderstelling in het model is tweeledig, en kan samengevat worden als het interactie-effect van taakeisen en energiebronnen op zowel stressreacties als bevlogenheid (de onderbroken lijnen in - Figuur 2.7). Enerzijds wordt verwacht dat energiebronnen de ongewenste invloed van takeisen op stressreacties (zoals burnout) en daarmee op negatieve uitkomsten kunnen compenseren. Met andere woorden, energiebronnen hebben een stressbufferend effect (zie $\rightarrow$ H. 10). Anderzijds zullen energiebronnen vooral een positief effect op motivationele aspecten als bevlogenheid hebben als het er echt om gaat, dus als de taakeisen hoog zijn. Dit is logisch omdat er in de regel vooral van hulpbronnen gebruik zal worden gemaakt wanneer dat nodig is. Zo krijgt bijvoorbeeld sociale steun vooral betekenis wanneer de werkdruk zo hoog is opgelopen dat men het alleen niet meer aankan. Welke taakeisen en energiebronnen er precies een rol spelen in een bepaalde organisatie, hangt af van de specifieke organisatie- en taakkarakteristieken die in een organisatie aanwezig zijn.

Recentelijk wordt ook de rol van persoonlijke hulpbronnen benadrukt in het JD-R Model (Bakker, 2011). Persoonlijke hulpbronnen zijn ontwikkelbare aspecten van een persoon, die helpen met stressvolle of onzekere situaties om te gaan. Voorbeelden van dergelijke hulpbronnen zijn persoonlijke effectiviteit, optimisme, eigenwaarde en zingeving. Deze aspecten dragen bij aan werkbevlogenheid. Zo laat onderzoek zien dat vertrouwen in eigen kunnen, optimisme en het gevoel mee te tellen in de organisatie de relatie tussen energiebronnen en werkbevlogenheid mediëren (Xanthopoulou e.a., 2007; 2009). Anders gezegd, energiebronnen lijken de ontwikkeling van persoonlijke hulpbronnen te stimuleren, die op hun beurt weer bijdragen aan werkbevlogenheid. Het JD-R Model en daarop gebaseerde online vragenlijsten wordt in Nederland door commerciële organisaties, zoals adviesbureaus en arbodiensten, in hun dienstverlening aan klanten gebruikt (Schaufeli \& Dijkstra, 2010).

\subsubsection{Empirische evidentie}

Uit onderzoekstudies die er tot nu toe over het JD-R Model of gedeelten daarvan zijn gedaan, blijkt dat de assumpties van het model in het algemeen worden bevestigd (Demerouti \& Bakker, 2011; Bakker \& Demerouti, 2007; Schaufeli \& Taris, in druk). Zo laten nagenoeg alle studies 
zien dat taakeisen en energiebronnen van elkaar kunnen worden onderscheiden en - zoals verondersteld - negatief met elkaar samenhangen. De positieve relatie tussen taakeisen en stressreacties (zoals burnout) wordt in nagenoeg alle studies gevonden, wat overigens ook geldt voor de positieve relatie tussen energiebronnen en bevlogenheid. Burnout en negatieve uitkomsten (met name gezondheidsklachten) zijn, evenals bevlogenheid en positieve uitkomsten (met name organisatiebetrokkenheid) in alle gevallen significant en positief aan elkaar gerelateerd. De meerderheid van de studies bevestigt voorts de mediatie van stressreacties (burnout) en bevlogenheid, ook in longitudinaal onderzoek. Naast dit indirecte effect is er soms ook sprake van een direct effect van taakeisen op negatieve uitkomsten, respectievelijk van energiebronnen op positieve uitkomsten. Tot slot is er ook empirisch bewijs voor de derde assumptie, te weten het interactie-effect van taakeisen en energiebronnen op zowel stressreacties als bevlogenheid (de onderbroken lijnen in - Figuur 2.7). Dit bewijs is echter minder sterk dan dat voor de directe effecten van taakeisen en energiebronnen. Zo bleek bijvoorbeeld dat de aanwezigheid van energiebronnen de negatieve invloed van takeisen op burnout vermindert. Een dergelijk buffereffect doet zich vooral voor in situaties waarin veel werkstress aanwezig is, in dat soort gevallen zijn energiebronnen immers het hardst nodig, zoals hierboven uiteen is gezet. Iets soortgelijks geldt ook voor bevlogenheid; namelijk, energiebronnen zoals autonomie hebben met name een versterkend effect op bevlogenheid wanneer de taakeisen hoog zijn en het dus van belang wordt om zelf keuzes te kunnen maken. Over de precieze rol die persoonlijke hulpbronnen in het JD-R Model spelen bestaat nog geen eenduidigheid. In hun overzicht van onderzoek met het JD-R Model concluderen Schaufeli en Taris (in druk) dat persoonlijke hulpbronnen:

1. een directe invloed op stressreacties en bevlogenheid kunnen hebben (bijv. emotioneel minder stabiele werknemers zullen snelle opgebrand raken);

2. het effect van taakeisen en energiebronnen op respectievelijk stressreacties en bevlogenheid kunnen versterken of verzwakken (moderator-effect; bijv. de positieve invloed van energiebronnen op bevlogenheid is sterker bij werknemers met veel zelfvertrouwen);

3. een schakel kunnen vormen tussen taakeisen en stressreacties, respectievelijk energiebronnen en bevlogenheid (mediatie-effect; bijv. de aanwezigheid van energiebronnen bevordert de waargenomen eigen competentie, hetgeen op zijn beurt weer tot bevlogenheid leidt);

4. de perceptie van taakeisen en energiebronnen kunnen beïnvloeden (bijv. optimisten zien meer energiebronnen in hun werk en pessimisten meer stressoren);

5. zowel de perceptie van taakeisen en energiebronnen kunnen beïnvloeden, als de werkbeleving (derde variabele effect; bijv. emotioneel minder stabiele werknemers zien hun werk eerder als stressvol en zijn tegelijkertijd ook kwetsbaarder voor burnout).

Kortom, het blijkt dat persoonlijke hulpbronnen op verschillende manieren van belang zijn.

\subsubsection{Kanttekeningen}

Evenals bij het P-E Fit Model is het JD-R Model vrij breed opgezet. Zo kunnen legio taakeisen en energiebronnen onderwerp van studie zijn. Welke taakeisen en welke werkhulpbronnen precies van belang zijn, wordt bepaald door de werksituatie die bestudeerd wordt. In feite is het JD-R Model een heuristisch model dat er, afhankelijk van de specifieke taakeisen en energiebronnen die in het geding zijn, steeds weer anders uit kan zien. Dit flexibele karakter van het JD-R Model is een belangrijke reden waarom het veelvuldig in de praktijk wordt gebruikt. Het JD-R Model maakt maatwerk mogelijk. 
Een tweede kanttekening betreft het statische karakter van het model. In de oorspronkelijke versie was er uitsluitend sprake van eenrichtingsverkeer: taakeisen leiden via stressreacties als burnout tot negatieve uitkomsten, terwijl energiebronnen via bevlogenheid tot positieve uitkomsten leiden. Echter, recenter onderzoek toont aan dat deze relaties ook omgekeerd kunnen lopen (zie ook Schaufeli \& Taris, in druk). Zo bleek uit een experiment onder studenten, die zoveel mogelijk reclameslogans moesten verzinnen, dat hun mate van bevlogenheid van invloed was op hun energiebronnen (controle over de tijd waarin, en de wijze waarop de taak moest worden uitgevoerd): hoe meer bevlogen ze zich voelden, hoe meer energiebronnen ze rapporteerden (Llorens e.a., 2007). Nadere analyse wees uit dat waargenomen eigen competentie ('self-efficacy') een sleutelrol speelde in een opwaartse spiraal die er als volgt uitzag: energiebronnen $\rightarrow$ self-efficacy $\rightarrow$ bevlogenheid $\rightarrow$ energiebronnen, enzovoort. Met andere woorden, er schijnt dus een cumulatie van energiebronnen plaats te vinden via een opwaartse spiraal ('gain spiral') waarin de mate van self-efficacy van centraal belang is (Salanova e.a., 2010). Een andere manier waarop de dynamiek van het JD-R Model onderzocht wordt vormen dagboekstudies, waarbij werknemers gedurende een aantal opeenvolgende dagen een (elektronisch) dagboek bijhouden van de taakeisen en energiebronnen die ze dagelijks op hun werk tegenkomen en van hun werkbeleving in termen van stressreacties en bevlogenheid. Zo bleek bijvoorbeeld dat de personeelsleden van een fastfoodrestaurant meer bevlogen zijn op dagen waarop ze zich door hun chef gesteund en gewaardeerd voelen dan op dagen waarop dat niet het geval is (Xanthopoulou e.a., 2009). Bovendien, en nog veel belangrijker voor het restaurant, de financiële omzet was juist op die dagen hoger.

\subsection{Demand-Induced Strain Compensation Model}

\subsubsection{Inhoud}

In 2001 ontwikkelden de A\&O-psychologen Jan de Jonge en Christian Dormann het Demand-Induced Strain Compensation Model (DISC Model; De Jonge \& Dormann, 2003; De Jonge \& Dormann, 2006. In Nederland wordt het model tegenwoordig ook wel het HoofdHart-Hand (H-H-H) Model genoemd (De Jonge \& Peeters, 2012). Het DISC Model borduurt voort op de (dis)balansgedachten van het DC Model en het ERI Model, doch is een meer omvattend theoretisch model voor werkstress en arbeidsmotivatie. Daarnaast wordt in het DISC Model aandacht besteed aan recente ontwikkelingen in arbeid, zoals de opkomst van de dienstensector en het daaraan gekoppelde - emotioneel belastende - werk met cliënten en patiënten (zie ook $\$ H. 13 en De Jonge, Peeters \& Le Blanc, 2006). De kern van dit model is dat werk grofweg bestaat uit hoofd-, hart- en handtaken en dito werkhulpbronnen, en dat mensen mentaal (hoofd), emotioneel (hart) en fysiek (hand) kunnen herstellen van hun werk (zie - Figuur 2.8).

Evenals in het JD-R Model zijn taakeisen díe aspecten in het werk die inspanning vragen en onderverdeeld kunnen worden in mentale, emotionele en fysieke taakeisen. Bij mentale taakeisen gaat het om taken die veel mentale inspanning vragen, zoals een complex probleem of een hoge concentratie. Emotionele taakeisen zijn taken die veel emotionele inspanning vereisen, zoals conflicten of confrontatie met agressie of lijden. Fysieke taakeisen ten slotte zijn taken die veel fysieke inspanning vragen, zoals zwaar tillen of lang achtereen staan. Hulpbronnen in het werk kunnen net zoals in het JD-R Model beschouwd worden als energiebronnen. Hierbij gaat het om aspecten die de werknemer in staat stellen tegemoet te komen aan de eisen die het werk stelt, dan wel leiden tot groei en ontwikkeling. Evenals taakeisen zijn ook werkhulpbronnen 


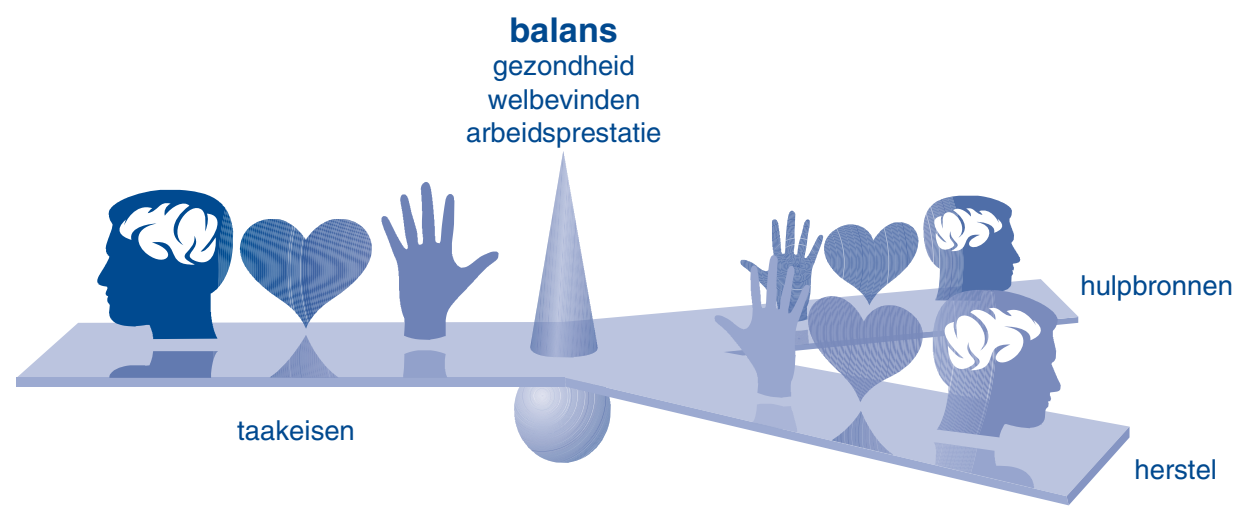

- Figuur 2.8 Demand-Induced Strain Compensation Model alias Hoofd-Hart-Hand Model.

in het DISC Model onder te verdelen in mentale, emotionele en fysieke hulpbronnen. Mentale werkhulpbronnen zijn hulpmiddelen op het mentale vlak, zoals de mogelijkheid om de eigen werkmethode te kiezen, zelf de volgorde van taken te bepalen of toegang te hebben tot informatie. Emotionele werkhulpbronnen zijn emotionele hulpbronnen en komen vooral tot uiting in emotionele steun van collega's of leidinggevende, of een luisterend oor na een emotioneel zware taak. Fysieke werkhulpbronnen zijn fysieke middelen, zoals technische en/of ergonomische hulpmiddelen, of een helpende hand van een collega.

In aanvulling op het JD-R Model kent het DISC Model nog een derde kernbegrip: herstel. Herstel van arbeid wordt in het DISC Model gedefinieerd als het volledig loskomen van het werk. In de Angelsaksische literatuur wordt dit 'detachment' genoemd (De Jonge, Zijlstra \& Sluiter, 2010). Ook voor herstel geldt een opdeling in mentaal, emotioneel en fysiek. Mentaal loskomen van het werk houdt in dat de werknemer niet meer aan het werk denkt. Emotioneel loskomen van het werk betekent dat hij niet meer nadenkt over emotioneel belastende werksituaties en de bijgehorende emoties ook niet meer ervaart. De werknemer wordt dan niet meer geraakt door emotionele situaties die zich op het werk afspeelden. Fysiek loskomen van het werk, ten slotte, betekent dat de werknemer niet meer dezelfde houding heeft als tijdens het werk, of hetzelfde type lichamelijke arbeid verricht. Denk bijvoorbeeld aan iemand die 's avonds weer achter een bureau gaat zitten, terwijl hij dat al de hele dag heeft gedaan.

De Jonge en Dormann hebben de zogeheten DISQ-vragenlijst ontwikkeld om de taakeisen en werkhulpbronnen van het DISC Model te meten. Dit van oorsprong Engelstalige meetinstrument is in diverse andere talen beschikbaar, waaronder Nederlands. Daarnaast is recentelijk een meetinstrument voor de drie dimensies van herstel ontwikkeld, de zogenoemde DISQ-R (zie bijvoorbeeld De Jonge e.a., 2012). Het raadplegen van de DISQ en DISQ-R kan op $\checkmark$ www.jandejonge.nl.

Het DISC Model is gebaseerd op zelfregulerende processen, die we overal in ons leven tegenkomen (zie Vohs \& Baumeister, 2004), en dus ook op het werk (Vancouver, 2000). Zelfregulatie in het werk betreft de inzet van functionele werkhulpbronnen om de effecten van specifieke taakeisen op de gezondheid en arbeidsmotivatie van een werknemer het hoofd te kunnen bieden. Zo zal een verzorgende bij het tillen van een zware, bedlegerige bewoner meer hebben aan een goede tillift dan aan een collega die haar vanaf de zijlijn aanmoedigt. De tillift is in dat geval een meer functionele werkhulpbron dan de collega.

Het DISC Model gaat uit van twee centrale principes. 
1. Multidimensionaliteit van concepten.Taakeisen, werkhulpbronnen, herstel en werkgerelateerde uitkomsten bestaan in beginsel uit mentale (hoofd), emotionele (hart) en fysieke (hand) dimensies. Zo kunnen taakeisen primair mentaal (bijv. hoge concentratie of veel informatieverwerking), primair emotioneel (bijv. veeleisende cliënten of confrontatie met stervende patiënten) of primair fysiek zijn (bijv. lang moeten staan of snelle bewegingen moeten maken). Voorbeelden van mentale uitkomstmaten zijn verminderde creativiteit en concentratieverlies, voorbeelden van emotionele uitkomstmaten zijn emotionele uitputting en depersonalisatie, en voorbeelden van fysieke uitkomstmaten zijn rugklachten en spierpijn.

2. Drievoudig matchingprincipe. Taakeisen, werkhulpbronnen, herstel en uitkomstmaten zijn sterker geassocieerd indien gelijksoortige concepten en processen een rol spelen (De Jonge \& Dormann, 2006; De Jonge e.a., 2012). Bijvoorbeeld, hoge mentale takeisen in combinatie met gebrek aan mentale werkhulpbronnen en mentaal herstel zullen primair leiden tot mentale (stress)reacties. Of: hoge fysieke taakeisen en gebrek aan fysieke werkhulpbronnen en fysiek herstel zullen primair leiden tot fysieke gezondheidsklachten. Zij passen allemaal als het ware goed bij elkaar (triple matching). Daarnaast kunnen persoonlijke groei, creativiteit en actief leren ontstaan wanneer de spanningsvolle opwinding ('arousal') die veroorzaakt wordt door een taakeis, omgebogen wordt in een directe, efficiente actie door de toepassing van een specifieke, passende of matchende werkhulpbron.

\subsubsection{Empirische evidentie}

Van den Tooren, De Jonge en Dormann (2011) hebben een overzicht van 29 empirische DISCstudies gepubliceerd, die als 'kwalitatief goed' uit de bus kwamen. Het overgrote deel van deze studies blijkt empirische ondersteuning te bieden voor het drievoudig matchingprincipe. Zo bleek bijvoorbeeld in een studie onder Nederlandse tabakshandelaren een drievoudige match tussen (hoge) emotionele taakeisen, (lage) emotionele werkhulpbronnen en de burnout-component 'emotionele uitputting. En bij Duitse en Nederlandse gezondheidszorgmedewerkers kwam naar voren dat vooral het interactie-effect tussen (hoge) mentale taakeisen en (hoge) mentale werkhulpbronnen positief samenhangt met actief leergedrag. Tot slot werd ook longitudinaal bewijs voor het drievoudig matchingprincipe gevonden. Zo bleek uit een panelstudie onder verpleeghuismedewerkers een significant interactie-effect tussen (hoge) fysieke taakeisen en (lage) fysieke werkhulpbronnen in de voorspelling van fysieke gezondheidsklachten twee jaren later. In een andere panelstudie onder Australische politieagenten werd een significant interactie-effect gevonden tussen (hoge) mentale taakeisen en (hoge) mentale werkhulpbronnen in de voorspelling van persoonlijke bekwaamheid. In het algemeen kwam uit het overzicht van Van den Tooren e.a. (2011) naar voren dat er vaker interactie-effecten gevonden werden naarmate er een match bestond tussen taakeisen, werkhulpbronnen én werkgerelateerde uitkomsten.

\subsubsection{Kanttekeningen}

Evenals bij het DC Model en het JD-R Model waren in het DISC Model oorspronkelijk enkel taakeisen en werkhulpbronnen als voorspellers opgenomen. Zoals hierboven geschetst is het model recentelijk uitgebreid met herstel. Zo blijkt uit een cross-sectionele studie van De Jonge e.a. (2012) dat hoge emotionele taakeisen en weinig emotioneel herstel gepaard gaan met 
gevoelens van emotionele uitputting. Tevens bleek dat hoge fysieke taakeisen, weinig fysieke werkhulpbronnen en weinig fysiek herstel gepaard gaan met fysieke gezondheidsklachten. De uitbreiding van het model met herstel lijkt een zinvolle toevoeging, maar vergt nader theoretisch en empirisch onderzoek.

Analoog aan het Person-Environment Fit idee over passing tussen persoon en werk, alsmede Warr's (2007) gedachtegang over matchende persoonskenmerken, is het DISC Model empirisch getoetst aan de hand van dergelijke matchende persoonskenmerken. Uit onderzoek weten we dat de gezondheid en het welbevinden van een werknemer ook afhangt van persoonskenmerken, zoals copinggedrag en doeloriëntaties. In overeenstemming met de DISC-assumpties wordt verondersteld dat persoonskenmerken moeten passen bij specifieke werkkenmerken, willen ze een effect hebben. Zo bleek uit een DISC studie onder gezondheidszorgmedewerkers dat bij personen met een hoge proactieve copingstijl de creativiteit toeneemt bij een toename van de mentale taakeisen, ongeacht of veel of weinig mentale werkhulpbronnen aanwezig zijn (De Hoon, Van Riet \& Schippers, 2005). In dit geval is het aannemelijk dat proactieve coping het gebruik en/of de aanwezigheid van mentale werkhulpbronnen overruled. Kortom, wanneer er sprake is van een match tussen het copinggedrag en de werkhulpbron is het effect nagenoeg zoals verwacht. Recent onderzoek van Van den Tooren (2010) naar de invloed van dit type persoonskenmerken laat echter zien dat deze kenmerken in een tweetal studies geen enkele rol van betekenis speelden. Ondanks dat het empirische bewijs op dit moment niet eensluidend is, lijkt het raadzaam om de rol van matchende persoonskenmerken in het DISC verder te bestuderen.

Een laatste kanttekening betreft de richting van mogelijke verbanden tussen werk en gezondheid. Evenals het JD-R Model is ook het DISC Model vrij statisch van karakter. Er is uitsluitend sprake van eenrichtingsverkeer: taakeisen, werkhulpbronnen en herstel leiden tot allerlei negatieve en positieve uitkomsten. Eerder onderzoek heeft aangetoond dat deze relaties ook omgekeerd kunnen lopen, of zelfs wederkerig kunnen zijn (zie bijv. Bakker \& Demerouti, 2007; De Jonge e.a., 2001), en dit zal dus ook binnen de context van dit model nader onderzocht moeten worden.

\section{$2.8 \quad$ Slotbeschouwing}

In dit tweede hoofdstuk zijn enkele theoretische modellen over werkstress besproken, die de groeiende belangstelling voor psychosociale werkkenmerken als determinanten van gezondheid en welbevinden reflecteren. Achtereenvolgens kwamen aan bod het Person-Environment Fit Model, het Demand-Control-Support Model, het Vitaminemodel, het Effort-Reward Imbalance Model, het Job Demands-Resources Model en het Demand-Induced Strain Compensation Model. Naast de bespreking van hun inhoud en empirische evidentie zijn ook kanttekeningen bij deze modellen geplaatst.

De vraag resteert wat nu de uniciteit is van ieder model. Allereerst zijn genoemde theoretische modellen te rangschikken van eenvoudig naar complex. Zo lijken het DC(S) Model en het ERI Model relatief eenvoudige modellen, terwijl P-E Fit Model als een relatief complex model beschouwd kan worden. Het Vitaminemodel, JD-R Model en DISC Model bevinden zich hier tussenin.

Ten tweede zijn alle modellen in meer of mindere mate te beschouwen als balansmodellen. Het risico op allerlei gezondheidsklachten en verminderd welbevinden ten gevolge van hoge taakeisen zal verminderen indien werknemers voldoende compensatie verkrijgen. Zo legt het P-E Fit Model de nadruk op persoonlijke behoeften, copinggedrag en sociale ondersteuning als compensatoire factoren. Het DC(S) Model richt zich op de mogelijkheden voor controle en 
sociale steun in het werk, terwijl het ERI Model meer nadruk legt op de beloningsstructuur van het werk. Binnen het JD-R Model kunnen allerlei soorten energiebronnen en persoonlijke hulpbronnen als compensatie dienen, terwijl het DISC Model expliciet uitgaat van drie soorten werkhulpbronnen en drie soorten herstel (mentaal, emotioneel, fysiek). Het Vitaminemodel, ten slotte, kan gekarakteriseerd worden als een 'enkelvoudig' balansmodel: de meeste werkkenmerken moeten eigenstandig in balans zijn, dat wil zeggen niet te veel en niet te weinig, al dan niet beïnvloed door bijpassende persoonskenmerken.

Ten derde bestaan er accentverschillen tussen de modellen: expliciete focus op het werk, de persoon, of op beide. Zo leggen het DC(S) Model en het DISC Model vooral de nadruk op werkkenmerken als oorzaken van werkstress, terwijl het P-E Fit Model vooral het accent legt op persoonskenmerken. De overige modellen kennen een hybride focus: zowel het werk als de persoon worden als oorzaken van werkstress opgevat, waarbij het JD-R Model en Vitaminemodel prioriteit toekennen aan werkkenmerken.

Ten vierde zijn alle modellen in meer of mindere mate te beschouwen als 'black box'modellen: er komt iets in en er gaat iets uit. Alle leggen de nadruk op wat stressreacties veroorzaakt, zonder diep in te gaan op het feit hoe en waarom stressreacties veroorzaakt worden. Het DISC Model doet hier wel een poging toe door gebruik te maken van de theorie over functionele, zelfregulerende processen. In dit perspectief kunnen zowel het P-E Fit Model als het JD-R Model beschouwd worden als heuristische modellen die, afhankelijk van de specifieke taakeisen en hulpbronnen (werk/persoon) die in het geding zijn, er steeds anders uit kunnen zien. Op dit vlak onderscheiden deze modellen zich van de overige modellen, waarin steeds sprake is van een vast omschreven aantal psychosociale risicofactoren.

Ten vijfde gaat het merendeel van de modellen in beginsel uit van lineariteit en eenrichtingsverkeer van relaties tussen werk/persoon en gezondheid. Het Vitaminemodel is het enige model dat een lans gebroken heeft voor niet-lineaire relaties, terwijl binnen het JD-R Model en DISC Model tegenwoordig ruimte is voor omgekeerde en wederkerige relaties.

Een laatste opmerking over werkstressonderzoek in het algemeen heeft betrekking op het gebrek aan gedegen interventie-onderzoek (zie ook $\neg$ H. 11). Een aanbeveling voor toekomstig onderzoek is om de assumpties van genoemde modellen gecontroleerd te toetsen in de praktijk. Interventiestudies waarbij gebruikgemaakt wordt van longitudinaal vragenlijstonderzoek, dagboekonderzoek, multiniveau-onderzoek en experimenten (zie $\bullet$ H. 10) zijn gewenst om de assumpties van de modellen grondiger te kunnen bestuderen, en aldus verdere modelontwikkeling alsmede aanbevelingen voor de praktijk mogelijk te maken.

\section{Aanbevolen literatuur}

Cooper, C.L. (Ed.) (1998). Theories of organizational stress. Oxford: Oxford University Press.

Demerouti, E., Bakker, A.B., Nachreiner, F., \& Schaufeli, W.B. (2001). The job demands-resources model of burnout. Journal of Applied Psychology, 86, 499-512.

Tooren, M. Van Den, Jonge, J. de, \& Dormann, C. (2011). The Demand-Induced Strain Compensation Model: Background, key principles, theoretical underpinnings, and extended empirical evidence. In A. Caetano, S.A. Silva, \& M.J. Chambel (Eds.), New challenges for a healthy workplace in human services (pp. 13-59). Mering: Rainer Hampp Verlag.

Karasek, R.A., \& Theorell, T. (1990). Healthy work: stress, productivity and the reconstruction of working life. New York: Basic Books.

Schaufeli, W.B. \& Taris, T.W. (in druk). A critical review of the Job Demands-Resources Model: Implications for improving work and health. Bauer \& O. Hämmig (Eds), Bridging occupational, organizational and public health. Amsterdam: Springer.

Warr, P. (2007). Work, happiness, and unhappiness. London: Lawrence Earlbaum. 


\section{Aanbevolen websites}

Informatie over psychische aandoeningen en werk: $>$ www.psychischenwerk.nl.

Overzicht van onderzoek met het JD-C model: $>$ www.workhealth.org en $\boldsymbol{\sim}$ www.unhealthywork.org

Overzicht van onderzoek met het ERI model: www.uni-duesseldorff.de/medicalsociology.

Overzicht van onderzoek met het JD-R model: www.wilmarschaufeli.nl en www.arnoldbakker.com

Overzicht van onderzoek met het DISC-model: $\$$ www.jandejonge.nI 